\title{
Embryo-toxic Effects Produced by Magnesium Deficiency in Rats
}

\author{
By Th. GüNther, F. Dorn and H. J. Merker ${ }^{1}$ ) \\ Zentralinstitut fïr Biochemie und Biopbysile und II. Anatomisches Institut der Freien Universität Berlin
}

(Eingegangen am 9. Oktober/8. November 1972)

\begin{abstract}
During pregnancy the $\mathrm{Mg}$-concentration in the serum of rats on a $\mathrm{Mg}$-rich diet showed no significant decrease, but the intracellular $\mathrm{Mg}$ content increased in the liver, muscle and heart. In pregnant rats on $\mathrm{Mg}$-deficient diets, resorption and retardation of fetuses were observed, and to a lesser extent, malformations of the extremities and the abdominal-wall of fetuses also occurred. The systematic variation of the onset and duration of $\mathrm{Mg}$-deficient-feeding demonstrated that the most marked effect is scen when the serum $\mathrm{Mg}$-concentration of the mother animal is decreased on day 10-11 of pregnancy.

In $\mathrm{Mg}$-deficient fetuses the $\mathrm{Mg}$-content was slightly decreased, the $\mathrm{K}$-content was greatly decreased, while the $\mathrm{Na}$-content was increased. In the electron microscope, the cells of the fetuses which were undergoing resorption showed membrane fragmentation and pycnosis of the nuclei.

New born rats of mother animals which had received a $\mathrm{Mg}$ deficient diet from day 5-12 of pregnancy showed a high death-rate. By histological examination we found a swelling of the mitochondria and a loss of lipid inclusions in the brown adipose tissue. In the brain there were necroses which showed no definite glia-reactions, a decrease in the number and thickness of the layers in the cortex and a hydrocephalus externus. Other organs were morphologically unchanged.
\end{abstract}

Während der Schwangerschaft sank die Mg-Konzentration im Serum Mg-reich ernährter Ratten nicht signifikant ab. Der Mg-Gehalt in Leber, Muskel und Herz nahm zu. Wurden schwangere Ratten Mg-arm ernährt, wurden Resorptionen, Retardation und in geringem Ausmaß Mißbildungen der Extremitäten und der Bauchwand beobachtet. Bei systematischer Variation von Beginn und Dauer der Mgarmen Ernährung ergaben sich die stärksten Effekte, wenn die Mg-Konzentration im Serum der Muttertiere am 10.-11. Schwangerschaftstage erniedrigt war.

In den Mg-Mangel-Feten war der Mg-Gehalt geringfügig und der K-Gehalt stark vermindert, während der Na-Gehalt erhöht war. Die Zellen der Foeten im Zustand der Resorption zeigten Fragmentierung der Membranen und Kernpyknose.

Neugeborene Ratten, deren Mütter von Tag 5-12 der Gravidität Mg-arm ernährt wurden, wiesen eine hohe Sterblichkeit auf. Wir fanden histologisch Mitochondrienschwellung und Verlust der Fetttropfen im braunen Fettgewebe. Im Gehirn traten Nekrosen ohne Gliareaktion auf. Es zeigte sich eine Abnahme der Zahl und Dicke der Hirnschichten sowie Hydrocephalus externus. Die anderen Organe waren morphologisch nicht verändert.

Considerable evidence has been accumulated that a deficiency of amino acids, vitamins or trace elements is able to produce embryotoxic effects in experimental animals $(1,2,3)$. But the consequences of a magnesium deficiency in the maternal organism on embryonic development have not yet been elucidated in detail. Since it is known that the concentration of magnesium is decreased during pregnancy in women $(4,5)$ it appears possible that a latent magnesium deficiency which may occur in men under conditions of an unbalanced food-intake could be exaggerated during pregnancy so that the embryo is confronted with a deficient supply of magnesium (for review 5,6 ).

We have studied the effect of a maternal magnesium deficiency on embryonic development of rats in some detail. Since it is well known that magnesium represents an essential co-factor in many enzyme reactions, including nucleic acid and protein synthesis reactions, embryonic tissue may provide a suitable model for studying the effect of magnesium deficiency on enzyme patterns, as well as on growth and differentiation processes. The rat was chosen for these studies because the change in magnesium concentration in blood and

1) Supported by grants from the "Deutsche Forschungsgemeinschaft" to the Sonderforschungsbereich 29. different tissues during magnesium deficiency is well known (7) and at the same time we have some information on the morphological and biochemical changes occurring during embryonic development in this species.

\section{Experimental Procedure}

Wistar rats of the strain SW 69 weighing $180 \mathrm{~g}$ were used for the studies. The animals were mated for a $2 \mathrm{hrs}$ period and the following $24 \mathrm{hrs}$ were called day 0 if sperm could be detected in the vaginal smear. The animals were fed an artificial $\mathrm{Mg}$-rich and $\mathrm{Mg}$ deficient food for different periods. The composition of the food has been described (7). The experimental series investigated are summarized in Table 3 . The pregnant rats of each group were sacrified on day 20 and the embryos removed, weighed and checked for macroscopic malformations. These fetuses were fixed in $100 \mathrm{~g} / \mathrm{l}$ formaldehyde, stained with alicarine and cleared with $\mathrm{Na} \mathrm{OH}$.

The methods for measuring $\mathrm{Mg}, \mathrm{Na}$ and $\mathrm{K}$-contents in the tissues have been described before (7). For the estimation of $\mathrm{Mg}$ in serum, $0.1 \mathrm{ml}$ of serum was deproteinized with $2 \mathrm{ml}$ of a solution containing $100 \mathrm{~g} / 1$ trichloroacetic acid and $1 \mathrm{~g} / 1$ Lanthanum as $\mathrm{LaCl}_{3}$.

For light and electron microscopical studies the embryos or new born rats were fixed in KARNOvSKX's solution (3\% glutaraldehyde and $3 \%$ paraformaldehyde in $0.1 \mathrm{~mol} / 1$ cacodylate buffer, $\mathrm{pH} 7.2$ ). For light microscopical examinations the embryos had to be additionally fixed in KARNovskY-solution before embedding in paraplast. They were stained with hematoxylin cosin as well as 
by the PAS- and Trichrome-methods. For the electron microscopical studies the fixation in KaRNOVSKY was followed by dehydration with acetone and an embedding in micropal (Firma Ferak Berlin). Butting was performed with a LKB-Ultrotome and the sections were contrasted with uranylacetate-lead acetate. A Siemens Elmiscope I and Ia were used.

\section{Results}

\section{General behaviour}

Symptoms of magnesium deficiency usually appear after more than one week on a Mg-deficient diet, so that up to one week of $\mathrm{Mg}$-deficiency, experimental animals showed no typical symptoms. The groups fed the $\mathrm{Mg}$ deficient diet for two or three weeks showed the $\mathrm{Mg}$ deficient symptoms to a lesser degree than non pregnant animals; i. e., redness of the ears and scrawls, but no necroses at the ears and no cramp.

\section{Magnesium metabolism}

The magnesium concentration in the serum of pregnant rats under our conditions of $\mathrm{Mg}$ nutrition showed no significant decrease in contrast to some observations in women. This may be due to the high $\mathrm{Mg}$-content of our normal diet. :

During the 8 days following the commencement of the magnesium depleted diet, the magnesium concentration of the serum declines from $1.07 \mathrm{mmol} / 1$ to $0.3 \mathrm{mmol} / \mathrm{l}$ and then stays about constant at about $0.23 \mathrm{mmol} / \mathrm{l}$ during the experimental period (Fig. 1). This decrease is more rapid and reaches a lower value than in non pregnant animals during $\mathrm{Mg}$-deficiency, which shows the higher $\mathrm{Mg}$-requirement in pregnancy.

The magnesium content of some of the maternal tissues, especially liver, heart and muscle, increased during pregnancy. This intracellular magnesium accumulation is also observed in liver and muscle when the magnesium concentration in serum is drastically reduced by a magnesium depleted diet (Tab. 1).

In 12 day old rat embryos, the mothers of which had been fed a magnesium depleted diet from day $0-12$, changes in electrolyte metabolism characteristic for

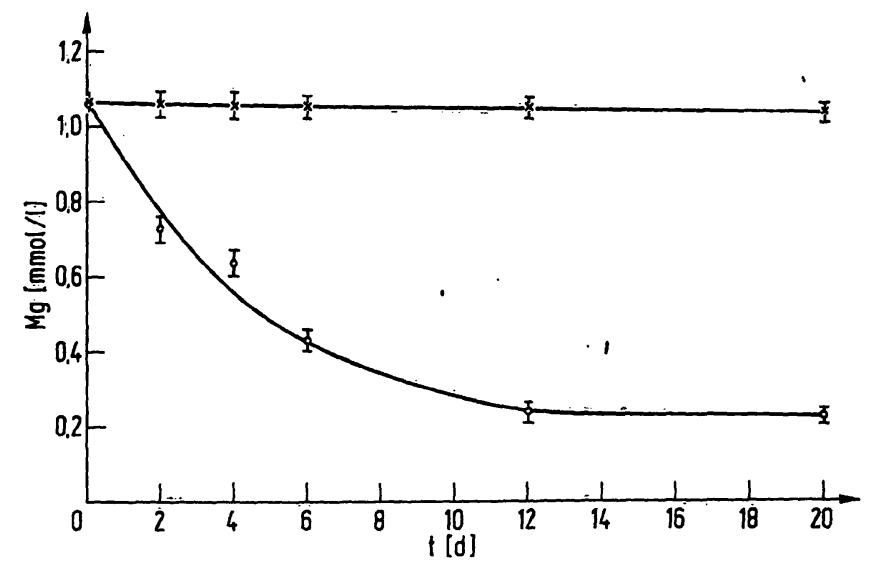

Fig. 1

Mg-conçentration in serum of rats during pregnancy . $\times$ rats fed a $\mathrm{Mg}$-rich artificial food (7)
$\mathrm{O}$ rats fed a $\mathrm{Mg}$-poor artificial food (7)

Tab. 2

Electrolyte contents from 12 day old embryos whose motheranimals were fed $\mathrm{Mg}$-poor food from day $0-12$. The mean \pm standard error of the mean was determined from 6 fetuses of 3 mother animals in each group. DNA was estimated according to SchMIDr, G. and Thannhauser, S. J. (1945), J. Biol. Chem. 161, 83-89

\begin{tabular}{lccc}
\hline & $\mathrm{Na}$ & $\mathrm{K}$ & $\mathrm{Mg}$ \\
\hline Control-fetuses & $31.8 \pm 1.0$ & $\begin{array}{c}{[\mu \mathrm{mol} / \mathrm{mg} \mathrm{DNA}]} \\
24.4 \pm 0.2\end{array}$ & $1.42 \pm 0.04$ \\
\hline Mg-deficient-fetuses & $33.4 \pm 0.6$ & $15.4 \pm 0.5$ & $1.11 \pm 0.05$ \\
\hline
\end{tabular}

magnesium deficiency could be observed: in addition to a decline in the magnesium content we found a pronounced decrease in the potassium concentration and a small increase in the sodium content (Tab. 2).

\section{Macroscopical Results}

\section{Rate of resorption}

In some of the experimental series the rate of resorption was very high. The results are summarized in Table 3. It may be seen that fetal lethality of approximately $100 \%$ is obtained if the magnesium deficient diet is

Tab. 1

Mg contents in different organs. Pregnant rats were fed Mg-rich [for ingredients see (7)] or Mg-poor (Mg-poor laboratory-food) diets for various periods. The mean \pm standard error of the mean was determined from 6 animals respectively

\begin{tabular}{|c|c|c|c|c|c|c|}
\hline & Day 0 & Day 3 & Day 6 & Day 12 & Day 18 & Day 20 \\
\hline \multicolumn{7}{|c|}{ Mg content (mmol $/ \mathrm{kg}$ dried substance) } \\
\hline Liver & & & & & & \\
\hline $\begin{array}{l}\text { Mg-rich food } \\
\text { Liver }\end{array}$ & $28.51 \pm 0.25$ & $27.76 \pm 0.50$ & $30.14 \pm 0.02$ & $29.92 \pm 0.07$ & $32.32 \pm 0.87$ & $33.38 \pm 0.15$ \\
\hline $\begin{array}{l}\text { Mg-poor food } \\
\text { Muscle }\end{array}$ & $27.95 \pm 0.27$ & $27.06 \pm 0.54$ & $29.80 \pm 0.29$ & $27.90 \pm 0.20$ & $29.40 \pm 0.47$ & $31.30 \pm 0 . \overline{74}$ \\
\hline $\begin{array}{l}\text { Mg-rich food } \\
\text { Muscle }\end{array}$ & $43.77 \pm 0.20$ & $45.05 \pm 0.15$ & $44.63 \pm 0.27$ & $45.30 \pm 0.20$ & $45.52 \pm 0.47$ & $45.65 \pm 0.55$ \\
\hline $\begin{array}{l}\text { Mg-poor food } \\
\text { Kidney }\end{array}$ & $43.48 \pm 0.19$ & $42.23 \pm 0.43$ & $44.80 \pm 0.32$ & $45.11 \pm 0.32$ & $44.96 \pm 0.26$ & $45.83 \pm 0.22$ \\
\hline $\begin{array}{l}\text { Mg-rich food } \\
\text { Heart }\end{array}$ & $32.39 \pm 0.30$ & $31.57 \pm 0.08$ & $32.11 \pm 0.60$ & $32.64 \pm 0.28$ & $32.63 \pm 0.92$ & $32.69 \pm 0.03$ \\
\hline $\begin{array}{l}\text { Mg-rich food } \\
\text { Bone }\end{array}$ & $37.57 \pm 0.15$ & $37.95 \pm 0.15$ & $\quad 37.93 \pm 0.46$ & $37.70 \pm 0.40$ & $38.97 \pm 0.72$ & $39.70 \pm 0.30$ \\
\hline Mg-rich food & $161.93 \pm 1.29$ & $165.25 \pm 1.74$ & $164.66 \pm 1.54$ & $158.75 \pm 1.74$ & $157.75 \pm 2.00$ & $164.62 \pm 1.24$ \\
\hline
\end{tabular}


Tab. 3

Resorptions and malformations of fetuses from rats that had been placed on $\mathrm{Mg}$-deficient food

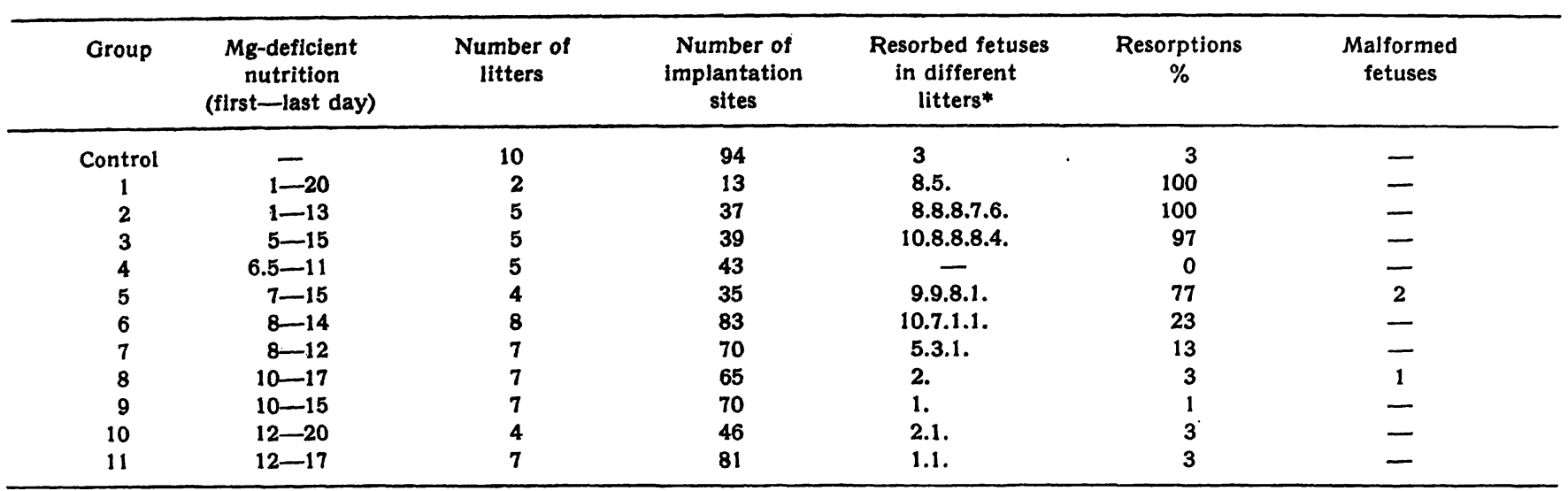

* Each figure gives the resorptions in one rat.

given during the whole pregnancy (day $0-20$ ) or from day $1-13$ p. c. and day 5-15 p. c. respectively. An analysis of the systematic variations of the magnesium deficient food period reveals that the rate of resorption is always high when the magnesium concentration in the serum of the mother animals is low at day 11 of pregnancy. To reach such low values, the magnesium deficient food must be given for 5-6 days (Fig. 1). If this period is too short, the magnesium concentration in the maternal serum does not decrease enough to allow an embryo-toxic effect. If the magnesium deficient diet is started later than on day 10 of pregnancy, the number of resorptions does not differ significantly from that of controls. When the magnesium deficiency was reached at about day 13 of pregnancy, the resorptions in general were confined to a few mother animals while others show very few resorptions.

\section{Wet weight of fetuses}

The weights of fetuses obtained by Caesarian section on day 20 of pregnancy are summarized in Table 4 . While in the experimental group 1-3 no viable fetuses were observed, there was a significant decline in the average wet weight of the fetuses from the experimental groups $4,5,7$ and 8 . No significant deviation from the controls was observed when the magnesium deficient food was given during days $8-14,10-15$, or $12-17$.

\section{Malformations}

Surprisingly, very few malformations were observed in our studies. The rate of spontaneous malformations in our strain is only $0.3 \%$. There were two malformations in the experimental group 5 and one in the experimental group 8. We feel that further experiments are necessary to elucidate this question, because these results don't agree with those of HurLey (5).

Two malformations affected the extremities, in one case the two upper, in the other all extremities (dysmelies) were shortened. During the clearing and Alizarin-redstaining, a marked shortening of the long bones of the extremities was found, but all the important skeleton-

Tab. 4

Wet weights of fetuses and placentae from rats that had been placed on Mg-deficient food for different time intervals during pregnancy

\begin{tabular}{|c|c|c|c|c|c|}
\hline Group & $\begin{array}{c}\text { Mg-deficient } \\
\text { nutrition } \\
\text { (first-last day) }\end{array}$ & $\begin{array}{c}\text { Fetuses } \\
\text { examined }\end{array}$ & $\begin{array}{l}\text { Wet weights [g] } \\
\text { of fetuses } \\
\overline{\mathbf{x}} \pm s \overline{\mathbf{x}}\end{array}$ & $\begin{array}{l}\text { Significance of } \\
\text { wet weights to } \\
\text { controls }\end{array}$ & \\
\hline 1 & $1-20$ & - & - & - & . \\
\hline 2 & $1-13$ & - & - & - & \\
\hline 3 & $5-15$ & - & - & - & \\
\hline 4 & $6.5-11$ & 43 & $2.75 \pm 0.42$ & $p<0.001$ & \\
\hline 6 & $8-14$ & 64 & $3.18 \pm 0.21$ & $p>0.05$ & \\
\hline 7 & $8-12$ & 61 & $3.09 \pm 0.23$ & $p<0.001$ & \\
\hline 8 & $10-17$ & 63 & $3.04 \pm 0.21$ & $p<0.001$ & \\
\hline 9 & $10-15$ & 69 & $3.16 \pm 0.27$ & $p>0.05$ & \\
\hline 10 & $12-20$ & 43 & $3.07 \pm 0.33$ & $\mathrm{p}=0.01$ & \\
\hline 11 & $12-17$ & 79 & $3.18 \pm 0.42$ & $p>0.05$ & \\
\hline
\end{tabular}

* 1 litter. 
parts were present (Fig. 2 b). The length of the humerus and femur of control embryos are $2.59 \pm 0.15 \mathrm{~mm}$ and $1.78 \pm 0.16 \mathrm{~mm}$ respectively. In the malformations the corresponding values were $1.98 \mathrm{~mm}$ for the humerus and $1.21 \mathrm{~mm}$ for the femur. The third malformation shows a large abdominal fissure of prolapsing viscera (Fig. 2c).

\section{Miorpbological studies of embryos}

In 18 day embryos, whose mothers were fed a $\mathrm{Mg}$ deficient diet from day $1-13$ and which were in process of resorption, all celltypes and tissues were clearly damaged. The nuclei are here pycnotic or show a clear karyorhexis. Cell membranes and the membranes of the cytoplasmic organelles are disrupted locally. The adhesion disappears and the epithelium tissues are greatly loosened. With the electron microscope these changes in damaged embryos can be seen and registered more precisely. In the nucleus the clumping and fragmentation of the chromatin is striking. The cell organelles are balooned, fragmented in vesicles or almost lost. Only few cell's- show an intact cell membrane and in many cases only; fragments can be seen (Fig. 3).

\section{Post natal findings}

New born rats from mothers fed a Mg-deficient diet from day 5-12 showed a high death rate (Tab. 5). In

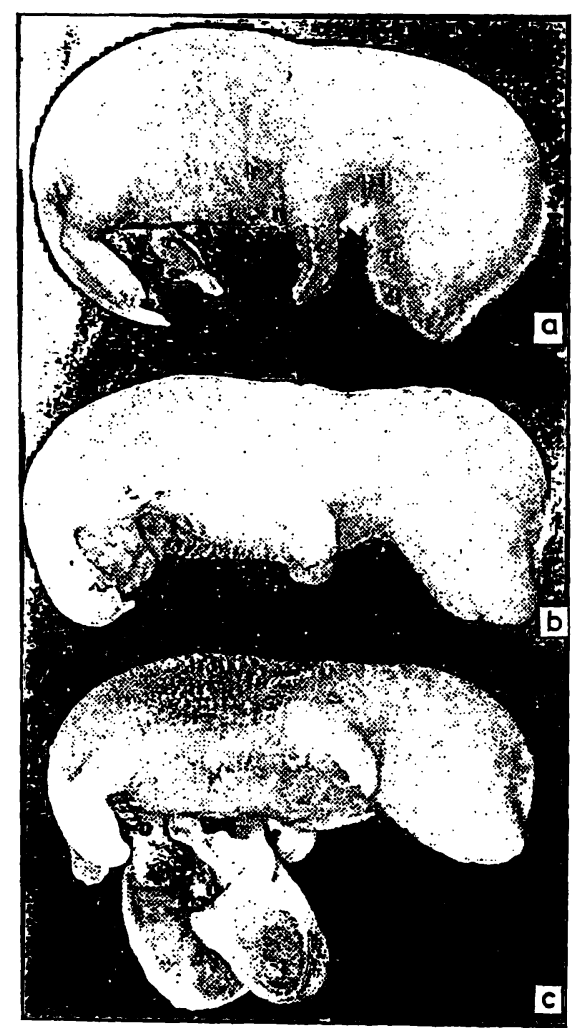

Fig. 2

Rat fetuses of day 20 from group $8,1 / 2$ natural size

b) Fetus with dysmelies af the upper extremity siren formation

c) Fetus with shortened snout and a pronounced defect of the front abdominal wall

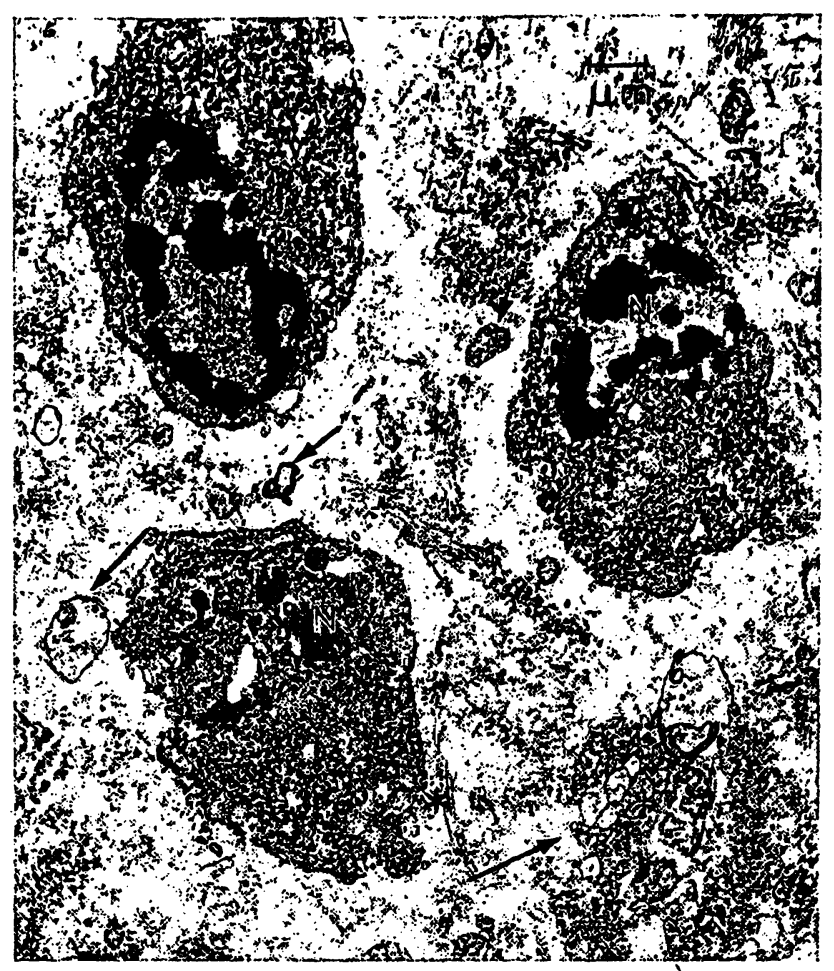

Fig. 3

Mesenchyma-region from the cutis area at the back of a 12-day-old embryo (fed on Mg-deficient diet from day 0 ). Fragmentated cell membrane and organell membrane. Cell fragments in the extracellular compartment $(\swarrow)$. Some additional small bundles of collagen fibrills $\left(^{*}\right)$ Obvious pycnotic nucleus (N)

Tab. 5

Number of new born rats which were dead at birth or died thereafter

\begin{tabular}{lcccc}
\hline $\begin{array}{c}\text { Mother } \\
\text { animals }\end{array}$ & $\begin{array}{c}\text { Number of new borns } \\
\text { living }\end{array}$ & $\begin{array}{c}\text { New borns dying in period } \\
\text { day } 0-4 \\
\text { post } \\
\text { partum }\end{array}$ & $\begin{array}{c}\text { day 4-21 } \\
\text { post } \\
\text { partum }\end{array}$ \\
\hline $\begin{array}{c}\text { Control } \\
{[\mathrm{n}=10]}\end{array}$ & 81 & 0 & 2 & 0 \\
$\begin{array}{c}M g \text { deficient } \\
\text { diet day } \\
5-12\end{array}$ & & & & \\
{$[\mathrm{n}=10]$} & 45 & 8 & 15 & 0 \\
\hline
\end{tabular}

similar experiments of WANG et al. (8) up to $90 \%$ of the new born rats died within the first week. In this case no pathological findings could be obtained macroscopically. Morphological investigations revealed, however, alterations in the brown adipose tissue and in the brain of the dead animals. The same was found in some animals which had been removed on day 20 by Caesarian section. The lipid inclusions in the brown adipose tissue (Fig. 4) which are very numerous before birth and after day 2 post partum had disappeared. At the same time a clear cut swelling of the mitochondria could be observed. Similar findings can be obtained from adult animals with a chronic $\mathrm{Mg}$-deficiency (9).

Necroses occur in the brain and they are located in the grey matter. Their location, however, is variable so that it is not possible to attribute them to specific brain regions. A pronounced glia cell reaction in the vicinity of the necroses is lacking (Fig. $5 b, c$ ). The number of layers and cells, and the thickness of the layers in the 


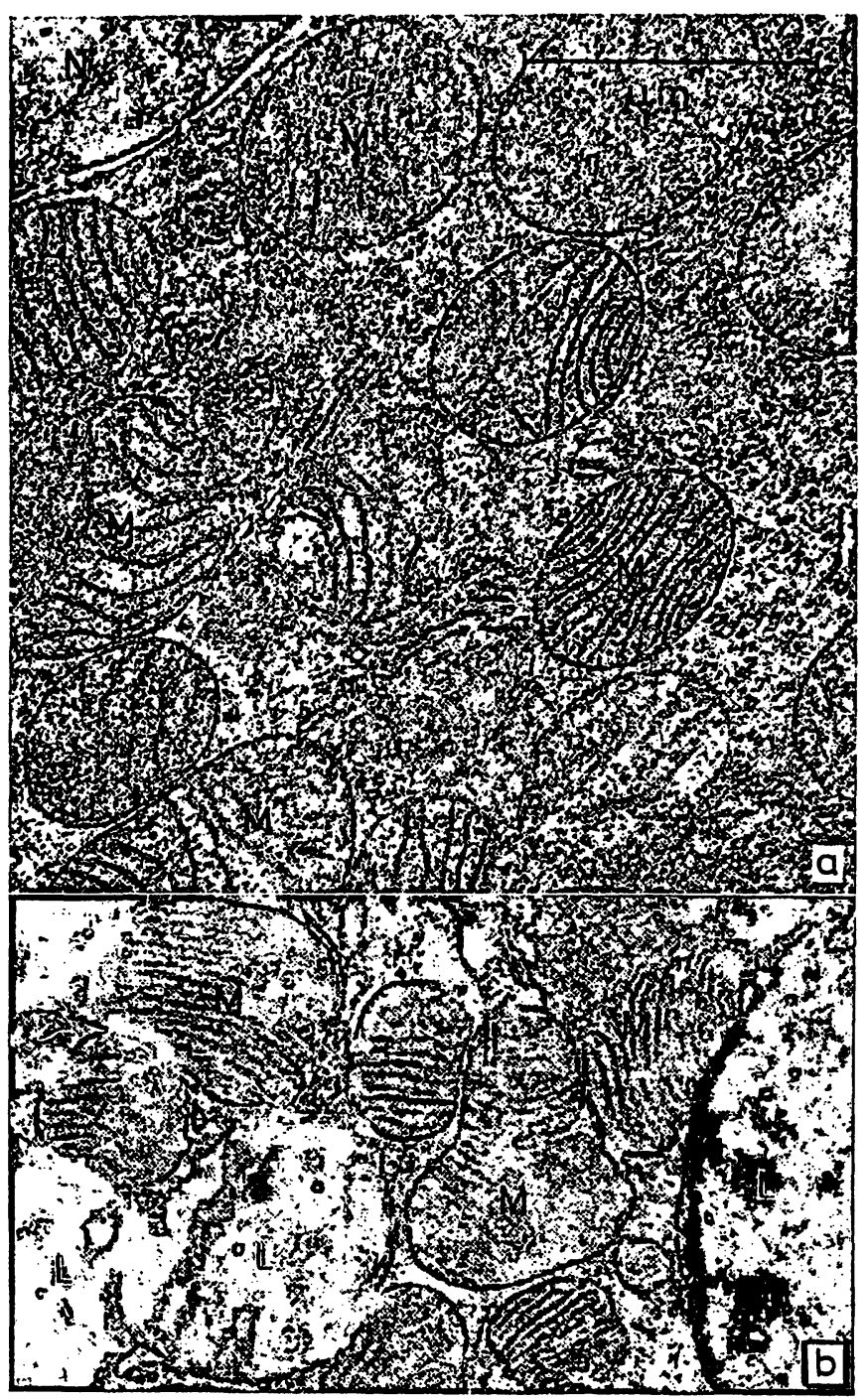

Fig. 4

a) Brown adipose tissue from a rat 3 days after birth with an obvious swelling of the mitochondria $(M)$. No lipid inclusions $\mathbf{N}=$ Nucleus

Magnification 1:28000

b) Brown adipose tissue from a control-rat Magnification: 1:28000

region of the telencephalon are reduced. Concomitant with a striking decrease in the thickness of the brain cortex wall, hydrocephalus externus can often be observed (Fig. 5a).

\section{Discussion}

During pregnancy there is an increased uptake of $\mathrm{Mg}$ in the intracellular compartment which may be produced by an increased level of oestrogen $(10,11)$. This $\mathrm{Mg}$ uptake also occurs in $\mathrm{Mg}$-deficiency, when the serum Mg-concentration is strongly decreased. Therefore, it follows that during pregnancy $\mathrm{Mg}$ is transported into the cells. In $\mathrm{Mg}$-deficient, pregnant rats, this $\mathrm{Mg}$ transport occurs against a higher electrochemical potential than in pregnant and non-pregnant controlanimals. As a result of the changed $\mathrm{Mg}$-distribution and the higher $\mathrm{Mg}$-requirement by the developing fetuses the $\mathrm{Mg}$-concentration in the serum can decrease if the $\mathrm{Mg}$-input is not sufficient. Thus, even in humans, a
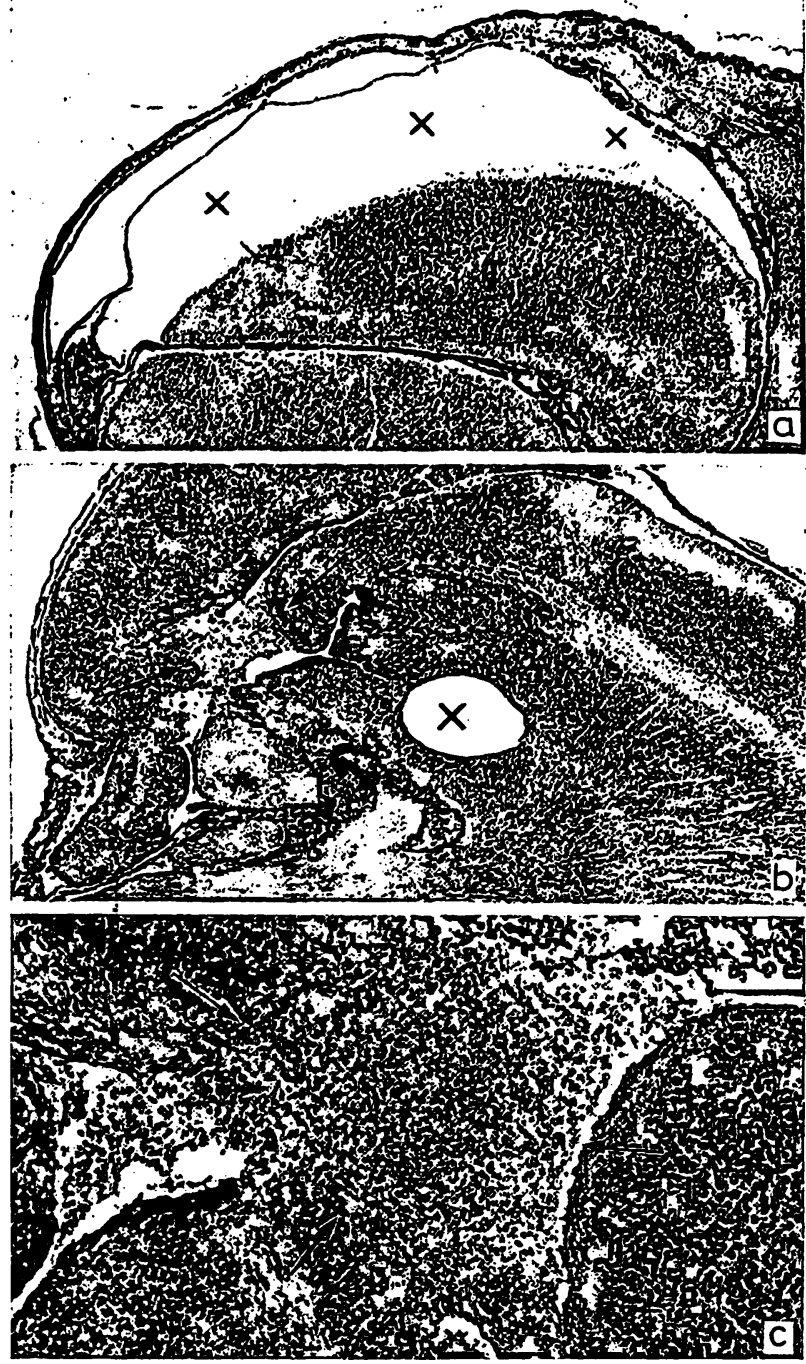

Fig. 5

New born rats (mothers fed on $M g$-deficient diet from day 5 to 12) a) Hydrocephalus externus $(x)$, tangential section through the

b) Necrotic area $(\swarrow)$, disturbing the normal construction of the brain in the neighbourhood, $x=$ old necrotic zone, transformed to a

c) Higher magnification of a similar necrotic zone

latent $\mathrm{Mg}$-poor nutrition, additional increased $\mathrm{Mg}$-need through protein-rich nutrition, a diminished $\mathrm{Mg}$ resorption in the intestine, e. g., through Ca-richnutrition, or increased loss of $\mathrm{Mg}$, through diuresis or alcohol could possibly lead to $\mathrm{Mg}$ concentrations that are embryotoxic.

The alterations described in the mineral metabolism of the $\mathrm{Mg}$-deficient fetuses are also found in other $\mathrm{Mg}$ deficient cells and tissues and are probably not a direct consequence of a decrease of the intracellular Mg-ionactivity. As the total $\mathrm{Mg}$-concentration of the fetuses is only little reduced (Tab. 2) and because the intracellular $\mathrm{Mg}$ is buffered (12) the intracellular Mg-ion-activity should remain constant.

In $\mathrm{Mg}$-deficiency there is a heavy decrease in the extracellular $\mathrm{Mg}$ and in the intracellular $\mathrm{K}$-concentration, and a slight increase in the Na-concentration (13). This is not caused by an alteration of active $\mathrm{K}$-transport but by an increase in the K-efflux from the cell. This is accompanied by a decrease in the rate of synthesis of 
DNA and protein $(13,14)$ and also of lipids in the brain (15). This inhibition of lipid synthesis in Mg-deficiency may be the reason for changes in the brain. On day 11 of gestation the nerve cell processes of the rat begin to grow. This brings about a great increase in cell surface and thus a high demand for membrane lipids. If this process is disturbed by $\mathrm{Mg}$-deficiency some centres may not be connected with one another. Subsequently necroses might occur.

Another cause for the high death rate may be the alterations in the brown adipose tissue. This tissue plays an important role in temperature regulation, especially after birth. In normal new borns immediately after birth the lipid droplets are dissolved and oxidative phosphorylation in the brown adipose tissue is uncoupled. A few days later lipids are again restored (16, 17). The loss of lipid droplets and the swelling of the mitochondria in the brown adipose, tissue of $\mathrm{Mg}$ deficient fetuses at day 21 of gestation may indicate that the cold acclimatisation in these animals is disturbed.

\section{References}

1. Giroud, A. (1967), Fed. Proc. 27, 163-184. - 2. Hurley, L. S. (1967), Fed. Proc. 27, 193-198. - 3. O'DeLL, B. L. (1967), Fed. Proc. 27, 199-204. - 4. De Jorge, F. B., Delascio, D., UlmoA Cintra, A. B. D. \& Antunes, M. L. (1965), Obstet. Gyn. 25, 253-254. - 5. HurLEY, L. S. (1971), In J. Durlach: 1. Internat. Symp. über den Mg-Mangel in der Menschl. Pathol., Vittel, p. 481-492. - 6. SEELIG, M. S. (1971), In J. Durlach: 1. Internat. Symp. über den Mg-Mangel in der Menschl. Pathol., Vittel, p. 11-38. - 7. GüNTHeR, $T_{H}$ (1970), this J. 8, 65-72. - 8. Wang, F. L., Wang, R., Khatrallah, E. A. \& Schwartz, R. (1971), J. Nutrition 101, 1201-1210. - 9. GüNTHER, TH.,
Schmalbeck, J., Dorn, F. \& Merker, H. J. (1972), This J. 10, 425-429. - 10. GüNTHER, Th. \& Alter, C. (1967), This J. 5, 67-72. - 11. Elghamr, M. I., HASSANIEN; R. R. \& Elmongy, S. A. (1971), This J. 9, 346-347. - 12. GüNTHER, TH. (1966), Z. Naturforsch. B 21, 1174-1177. - 13. GüNitHER, TH. \& AVERDUNK, R. (1970), This J. 8, 621-625. - 14. LuBIN, M. (1967), Nature 213, 451-453. - 15. Zoumas, B. L. \& BarRoN, G. P. (1969), Fed. Proc. 28, 556. - 16. SMITH, R. E. \& HoRwITz, B. A. (1968), Physiol. Rev. 49, 330. - 17. LINDBERg, O. (1970), Brown adipose tissue, Elsevier, New York.
Prof. Dr. Th. Günther 1000 Berlin 33 Arnimallee 22 